\title{
Florida Crop/Pest Management Profile: Papaya ${ }^{1}$
}

\author{
Mark A. Mossler and Jonathan Crane ${ }^{2}$
}

\section{Production Facts}

- Papaya (Carica papaya) acreage has fluctuated throughout the past several decades with hurricanes and urban encroachment. As high as 400 acres, Florida production is now believed to be approximately 300 acres (1).

- Average yield can approach 25,000 pounds per acre. With a pack-out of 85 percent and a price of $\$ 0.30$ per pound, income from an acre of papaya would have been worth approximately $\$ 6,375(1)$.

- Based on estimated acreage, the papaya crop is worth approximately $\$ 1.9$ million.

\section{Production Regions}

Most Floridian papaya is grown exclusively in South Florida. Over ninety percent of Florida's papaya production acreage is located in Miami-Dade County. The remaining acreage is primarily located in counties adjacent to MiamiDade County (1).

\section{Production Practices}

The papaya is a giant herbaceous dicotyledonous plant, which may produce fruit for more than 20 years. Plants grown in fertile well-drained soil may grow to a height of 10 meters or more. The structure is often comprised of a single stem, but several branches may develop as plants grow older. The stem wood is soft and pulpy. Leaves are large, deeply lobed, and may measure almost a meter in width with half-meter long petioles. The fruit are variable in size, and hang from short, thick peduncles at the leaf axils $(2,3)$.

Being a polygamous species, plants may be classified into three primary sex types: male (staminate), hermaphroditic (both sexes), and female (pistillate). Other reproductive considerations include the fact that some plants can produce more than one kind of flower at the same time and that some plants produce flowers which are not of the three basic forms, but are a mixture of male and female qualities. The tendency to change in sexual expression seems to be governed by climatic factors, such as drought and variable temperatures (3).

Since male plants are unfruitful, and the hermaphrodite fruit is desired in some markets, it is very important to select seed which will give a maximum number of fruitbearing plants. Saved seed from open-pollinated plants is not predictive of plant sex. However, hand pollination of

1. This document is CIR 1402, one of a series of the Horticultural Sciences Department, Florida Cooperative Extension Service, Institute of Food and Agricultural Sciences, University of Florida. Original publication date, September 2002. Original authors included O. Norman Nesheim, professor, Food Science and Human Nutrition Department. This publication was revised November 2009. Reviewed July 2013. For additional Information, contact the Pesticide Information Office, University of Florida, P. O. Box 110710, Gainesville, FI 32611-0710, (352) 392-4721. Published as CIR 1402: March 2002. Please visit the EDIS website at http://edis.ifas.ufl.edu.

2. Mark A. Mossler, pest management information specialist, Department of Agronomy, Pesticide Information Office; and Jonathan Crane, professor, Horticultural Sciences Department, Tropical Research and Education Center, Homestead, Florida; Cooperative Extension Service, Institute of Food and Agricultural Sciences, University of Florida, Gainesville, FL 32611-0710.

All chemicals should be used in accordance with directions on the manufacturer's label. Use pesticides safely. Read and follow directions on the manufacturer's label. The use of trade names in this publication is solely for the purpose of providing specific information. UF/IFAS does not guarantee or warranty the products named, and references to them in this publication do not signify our approval to the exclusion of other products of suitable composition.

The Institute of Food and Agricultural Sciences (IFAS) is an Equal Opportunity Institution authorized to provide research, educational information and other services only to individuals and institutions that function with non-discrimination with respect to race, creed, color, religion, age, disability, sex, sexual orientation, marital status, national origin, political opinions or affiliations. U.S. Department of Agriculture, Cooperative Extension Service, University of Florida, IFAS, Florida A\&M University Cooperative Extension Program, and Boards of County Commissioners Cooperating. Nick T. Place, Dean 
known sexes has led to the following four general rules. Pistillate flowers pollinated by staminate flowers produces an equal mixture of male and female progeny. Pistillate flowers pollinated by bisexual flowers give rise to an equal number of female and bisexual progeny. Bisexual flowers self- or cross-pollinated with other bisexual flowers give rise to progeny with a ratio of one female to every two hermaphrodites. Finally, bisexual flowers crossed with staminate flowers produce equal numbers of female, male, and hermaphroditic progeny. Consequently, the second and third combinations provide the most fruitful progeny. There are no true cultivars in Florida-grown papaya (3).

Papaya thrives under warm conditions with abundant rainfall or irrigation. It cannot tolerate strong winds, flooding, or frosts, and it recuperates very slowly if it has sustained considerable leaf or root injury. Temperatures below freezing usually cause severe damage or death. Soils should be well drained, as papaya is very sensitive to even short periods of flooding. However, supplemental irrigation should be available, as fluctuating water supply may cause growth retardation, flower abortion, and premature fruit drop. As papaya is fast-growing under these conditions, fertilizer must be used to be commercially productive (3).

Most commercially-grown papaya is propagated from seed. Two or three seeds are planted in peat pots, which are directly transferred to the ground when the seedlings maintain a height of 6 to 8 inches. Each planting is rogued to one plant once the sex has been determined. Rows are maintained between 12 and 15 feet apart and distance between plants in any given row is approximately 8 feet. This spacing translates to a density of 360 plants per acre (3, 4).

If seedlings are set in February or March, blooming commences in about five months, and it is possible to harvest fruit in October or November. If plants are set in May or June, good yields cannot be expected before the following April or May. Fruit are generally harvested for two years (20 to 30 pickings per year), after which plant height makes harvesting difficult $(3,4)$.

Papaya trees are picked by hand or by using a long picking pole which has at its distal end a canvas or nylon bag attached to a metal ring with a cutting blade. Ladders and hydraulic lifts are also used to enable pickers to reach fruit. A worker can generally pick up to three acres daily (1).

Computer-aided pest management of tropical fruit has been implemented by the University of Florida, Institute of Food and Agricultural Sciences. The TFRUIT•Xpert diagnostic program has been developed to assist growers and others in determining diseases, insect pest problems and physiological disorders (http://ifasbooks.ifas.ufl.edu/p-381-tropicalfruits-cd.aspx ).

\section{Insect/Mite Management Insect/Mite Pests}

The principal pests on papaya in Florida are papaya fruit fly, two-spotted spider mite, and papaya whitefly. Scales (Philephedra, soft brown), aphids, Diaprepes weevil, and papaya mealybug are other pests which occasionally limit papaya production $(3,5)$.

\section{Papaya Fruit Fly (Toxotrypana curvicauda)}

The papaya fruit fly is the principal pest of Florida papaya. The insect was introduced into Florida in 1905, most likely from the West Indies on U.S.-bound papaya shipments. The fly has become established in southern Florida, and has spread to wherever this plant is grown. The larvae also feed on mango and milkweed as alternate hosts.

The adult fly is predominantly yellow marked with black. The female has a very long, slender abdomen with a greatly elongated curved ovipositor that exceeds the length of its body. The male resembles the female, although the abdomen is hairy and it lacks the ovipositor. The female deposits long $(2.5 \mathrm{~mm})$ slender eggs inside the fruit. The larva are white and typically resemble fruit fly larvae (cylindrical maggot shape, elongate, anterior end narrowed and somewhat recurved ventrally, with anterior mouth hooks). The pupae are stout and cylindrical with rounded ends, and vary in length from $8.5-12 \mathrm{~mm}$.

During its life, the female is capable of laying 100 or more eggs. They are deposited during the evening or early morning in groups of ten inside young fruit and hatch in about 12 days. The young larvae feed on developing seeds and interior parts of the fruit. As the larvae mature, they begin to eat their way out of the fruit (about 16 days after hatch), drop to the ground, and pupate just below the soil surface. The mature flies emerge in about two to six weeks, depending upon humidity and temperature. Interestingly, unripe papaya juice is fatal to the larvae, so the flesh must be ripe when the larvae begin to migrate towards the surface. Fruit infected with papaya fruit fly larva will turn yellow and drop from the plant prematurely. Damage levels in Florida fluctuate between two and 30 percent of fruit infested during the spring-summer season $(6,7)$. 
Two-Spotted Spider Mite (Tetranychus urticae)

The two-spotted spider mite is oval in shape, about 0.5 $\mathrm{mm}$ long, and may be brown or orange-red, but a green, greenish-yellow or an almost translucent color is the most common. All mites have needle-like piercing-sucking mouthparts. Spider mites feed by penetrating the plant tissue with their mouthparts and are typically found on the underside of the leaf. Spider mites spin fine strands of webbing on the host plant- hence their name. When twospotted spider mites remove the sap, the mesophyll tissue collapses and a small chlorotic spot forms at each feeding site. Continued feeding causes a stippled-bleached effect on the upper surfaces of leaves and later, the leaves turn yellow, gray or bronze. Complete defoliation may occur if the mites are not controlled (8).

\section{Papaya Whitefly (Trialeuroides variabilis)}

Female whiteflies lay yellow oval eggs, which appear dusted, singly on the undersides of leaves. The nymphs go through three instars. The first instar or crawler has well-developed legs and is the only mobile immature life stage. After finding a suitable feeding site on the lower surface of a leaf, the crawlers insert their mouthparts, begin feeding, and usually do not move again while in the nymphal stage. The subsequent instars are flattened, oval, and scale-like. Whiteflies in the pupal stage are more convex, with large, conspicuous red eyes $(3,5)$.

\section{Chemical Control}

Sixty-six percent of responding surveyed papaya growers reported insecticide use (9). Those survey respondents that provided insect damage estimates indicated that from 30 to 100 percent of the papaya crop would be lost to insect damage ( $n=5$, mean of 62 percent).

Insecticides and miticides registered for use on Florida papaya in 2008 include azadirachtin, Bacillus thuringiensis, Beauveria bassiana, buprofezin, imidacloprid, insecticidal oil, insecticidal soap, malathion, permethrin, fenbutatinoxide, methidathion, methoxyfenozide, pyrethrin $+/$ rotenone, pyriproxyfen, spinetoram, spinosad, and sulfur, while pyriproxyfen and methoprene are available for fire ant control (10).

In non-bearing papaya, bifenazate and bifenthrin are registered while pymetrozine, fenpropathrin, and hexythiazox are labeled for non-bearing nursery papaya. Hydramethylnon is also available for fire ant control in non-bearing papaya.

\section{Permethrin}

Permethrin is a synthetic pyrethroid insecticide that interferes with normal nerve transmission. The compound is broad spectrum and used to control all of the pests previously mentioned. The median price of permethrin is $\$ 39$ per pound of active ingredient and the approximate cost per application is $\$ 8$ per acre $(9,11)$. Fifty percent of surveyed papaya growers applied permethrin either three (33 percent) or six (67 percent) times for an average use of 5.0 times per season (9). There is a material limit (1.2 pounds of active ingredient per acre per season) for permethrin use on papaya. The pre-harvest interval (PHI) is 7 days and the restricted entry interval (REI) is 12 hours (12).

\section{Malathion}

Malathion is an organophosphate insecticide used to manage sucking insects such as aphid and mealy bug (5). The price of malathion is $\$ 6$ per pound of active ingredient and the approximate cost per application is $\$ 7$ per acre (9, 11). Seventeen percent of surveyed papaya growers applied malathion to their acreage 4 times per season. The PHI is 0 days and the REI is 12 hours (13).

\section{Pyrethrin + Rotenone}

These two natural compounds both have contact and stomach activity. The mixture is used to manage sucking and chewing insects. The median price of the mixture is $\$ 900$ per pound of active ingredient and the approximate cost per application is $\$ 25$ per acre $(9,11)$. The PHI and REI for the mixture are both 12 hours (14). Seventeen percent of papaya growers reported the use of this tandem twice a season (9).

\section{Cultural Control}

Based on survey results of all tropical fruit growing respondents, 44 percent reported keeping records of pest problems, 50 percent adjusted applications (timing or rate) to protect beneficial insects and mites, and 52 percent alternated pesticides to reduce resistance. Sixty-two percent reported selecting the pesticide that is least toxic to beneficial insects and mites and 63 percent spot sprayed only infested plants or areas. Seventy percent reported selecting pesticides that are least toxic to the environment to make this the dominant form of cultural pest control (9).

\section{Biological Control}

Seven percent of the responding tropical fruit growers reported release of predatory wasps for control of 
lepidopterous pests. Additionally, 30 percent reported the use of biological-derived pesticides like B.t. (9).

\section{Weed Management}

\section{Weed Pests}

Weeds can reduce fruit yields by competing primarily for water and nutrients. Although individual weed species may vary regionally, predominant weed species in groves are grasses, sedges, and pigweeds (15).

\section{Chemical Control}

Fifty percent of surveyed papaya growers reported herbicide use. There are six herbicides labeled for use on bearing papaya (carfentrazone, glyphosate, paraquat, diuron, oryzalin, and pelargonic acid). Diquat and flumioxazin are registered for non-bearing papaya (10).

\section{Glyphosate}

Glyphosate is a phosphorylated amino acid herbicide used for total vegetation control. Glyphosate is applied as a directed spray so that foliage is not injured. The median price of glyphosate is $\$ 10$ per pound of active ingredient and the approximate cost per application is $\$ 20$ per acre for annual weeds and $\$ 50$ per acre for perennial weeds $(9,11)$. The REI for glyphosate is 4 hours and the PHI is 1 day (16). Fifty percent of surveyed papaya growers in Florida applied glyphosate either four (33 percent), six (33 percent), or nine (33 percent) times for an average use of 6.3 times per season (9).

\section{Paraquat}

Paraquat is a bipyridilium compound that quickly desiccates plant tissue and is used for total vegetation control by directed spray. The median price of paraquat is $\$ 12$ per pound of active ingredient and the approximate cost per application is $\$ 11$ per acre $(9,11)$. The REI for paraquat is 12 hours and the PHI is 0 day (17). Based on survey results, 17 percent of papaya growers in Florida applied paraquat twice per season.

\section{Diuron}

Diuron is a substituted urea compound that affects the photosynthesis of plants as it is absorbed by the roots. It should only be used under plants that are at least one year old and where the soil has an organic matter content greater than one percent. The median price of diuron is $\$ 6$ per pound of active ingredient and the approximate cost per application is $\$ 20$ per acre $(9,11)$. The REI for diuron is 12 hours (18). Based on survey results, 17 percent of papaya growers in Florida applied diuron twice per season.

\section{Disease Management Disease Pathogens}

The principal diseases affecting papaya include papaya ringspot virus, anthracnose (Colletotrichum gloeosporioides), powdery mildew (Oidium caricae), leaf spot (Corynespora cassiicola), and blight (Phytophthora spp.). Other diseases that intermittently affect papaya production are papaya droopy necrosis virus and yellow strap leaf (the latter resulting from a toxin produced by Aspergillus wentii, which is absorbed from the soil through the roots) $(4,19)$.

\section{Papaya Ringspot Virus}

Papaya ringspot is a potyvirus that is the most important disease of the crop in Florida, even to the point of limiting the potential for commercial production. Earliest signs of papaya ringspot virus infection appear as yellowing and vein-clearing of younger leaves. A prominent yellow mottling of the leaves follows. One or more lobes of infected foliage may become blistered, roughened, or narrow, with blades curving upwards from the midrib. Dark green greasy streaks may develop on the petioles and stems and the petioles become progressively shorter. However, the virus acquired its name by the striking signs that appear on the fruit. These consist of circles and C-shaped markings that are darker green than the natural color. Later, these markings may become gray and crusty in texture. Viral infection impacts growth, with reductions in fruit set and quality. Flavor is especially affected.

Although papaya ringspot virus can be transmitted mechanically, it is thought that aphid transmission is the most important mechanism for disease spread in the field. Currently, little can be done to control this virus. Aphicide applications, roguing, and physical separation of papaya fields have not been successful in controlling the disease. The University of Hawaii and collaborators have developed two varieties of papaya (SunUp ${ }^{\text {tw }}$ and Rainbow ${ }^{\text {rm }}$ ) which are resistant to the virus, but these are not resistant to the Florida strains of papaya ringspot virus. Current research is underway by the University of Florida to develop a resistant variety of papaya which will grow under the state's conditions (19).

\section{Anthracnose (caused by Colletotrichum gloeosporioides)}

The fungus attacks primarily the fruit of papaya, with mature fruit being more susceptible. Petioles and leaves 
may be infected, but this is thought to be important only as a source of the fungus for further fruit infection. The disease signs begin as small, water-soaked spots on ripening fruit. As the spots develop, they become sunken, turn brown or black, and may enlarge to a few inches. The fungus may produce a pink mass of spores in the middle of the older spots. The pathogen grows into the fruit, resulting in softening of the fruit and an off flavor. Growers practice a prophylactic program for this disease (19).

\section{Powdery Mildew (caused by Oidium caricae)}

This fungus is easily recognized by the presence of a white, superficial growth on the leaf surface. The disease begins as tiny, light yellow spots on the lower leaf surface. As the spots enlarge, a white powdery growth (fungal hyphae and spores) appear. Pale yellow spots then appear on the upper leaf surface at the infection position. In advanced stages, white fungal growth will develop on the upper leaf surface. Powdery mildew is not a severe problem but some leaf drop can occur (19).

\section{Leaf Spot (caused by Corynespora cassiicola)}

This is a disease primarily of the leaf blade but will occasionally occur on petioles and male flower stalks. It has not been observed on fruit or stems. Older leaves are most likely to be affected. Symptoms are first evident as small, yellow areas. Fully developed spots have a small $0.1 \mathrm{in}$. (2 $\mathrm{mm}$ ) brown center, with a prominent, yellow halo $0.2-0.4$ in. $(4-8 \mathrm{~mm})$. When leaf spots are examined closely, one may observe faint, concentric rings. C. cassiicola forms spores on both upper and lower leaf surfaces, but masses of spores are most evident on the latter. Examination of lower leaf surfaces with a hand lens for a dark growth of the fungus body and spores is important for diagnosis of this disease (19).

\section{Phytophthora Blight}

This fungus is capable of causing damping-off, root rot, stem rot, stem girdling, and fruit rot. Complete loss has been seen in some Miami-Dade fields. Cool, wet environmental conditions with high soil moisture favor disease development. Damping-off occurs in very young plants or in the field shortly after transplanting and is characterized by rapid wilting and plant death. Spots on the stems of established plants begin as water-soaked lesions, especially at fruit and branch scars. These areas can enlarge and girdle the plant, resulting in wilt and death of the plant top. Root infection can be severe and rapid. The first indication of major root infection often is rapid browning and wilting of the plants, followed by total collapse within days. The root infection also has a foul odor. Fruit infection is the most obvious aspect of the disease and potentially very important economically, because of the possibility of carry-over to the market. Water soaked spots are evidence that the fungus is present. Diseased fruit then become covered with a characteristic mass of whitish fungal growth. Fruit eventually shrivel and fall to the ground, where they serve as an important source of inoculum for root rot (19).

\section{Chemical Control}

Fifty percent of surveyed papaya growers reported fungicide use (9). Those survey respondents that provided damage estimates indicated that from 50-100 percent of the papaya crop would be lost to disease $(n=4$, mean of 78 percent). Fungicides registered for use on papaya include azoxystrobin, Bacillus subtilis, B. pumilus, copper, chlorothalonil, mancozeb maneb, mefenoxam, myclobutanil, carbonic acid, hydrogen peroxide, phosphites, and sulfur. Fungicides registered for use on papaya include azoxystrobin, Bacillus subtilis, B. pumilus, copper, chlorothalonil, mancozeb maneb, mefenoxam, myclobutanil, carbonic acid, hydrogen peroxide, phosphites, and sulfur. Thiabendazole is available for post-harvest treatment (10).

\section{Copper}

Copper has long been used as a fungicide and can be applied in multiple forms (copper hydroxide, copper sulfate, etc.). Copper is primarily used to manage anthracnose and leaf spot (18). The median price of copper hydroxide is $\$ 2$ per pound of active ingredient and the approximate cost per application is $\$ 20$ per acre $(9,11)$. The PHI and REI for copper hydroxide/copper sulfate are 0 days and 24 hours, respectively (21). Seventeen percent of surveyed papaya growers in Florida applied copper hydroxide three times to the crop.

\section{Mancozeb}

Mancozeb is used to manage anthracnose, leaf spot, and Phytophthora fruit rot (20). The median price of mancozeb is $\$ 5$ per pound of active ingredient and the approximate cost per application is $\$ 10$ per acre $(9,11)$. The PHI and REI for mancozeb are 0 days and 24 hours, respectively (20). Fifty percent of surveyed papaya growers in Florida applied mancozeb nine times (33 percent) or 24 times (67 percent) to the crop, for a seasonal average of 19 times. There is a seasonal limit of 28 pounds of active ingredient (20). 


\section{Mefenoxam}

Mefenoxam is used to manage Phytophthora-induced diseases as well as other soil-borne diseases in seedling plants (17). The median price of mefenoxam is $\$ 157$ per pound of active ingredient and the approximate cost per application is $\$ 130$ per acre $(9,11)$. The PHI and REI for mefenoxam are 90 days and 48 hours, respectively (17). Thirty percent of surveyed papaya growers in Florida applied mefenoxam once (50 percent) or twice ( 50 percent) to the crop, for a seasonal average of 1.5 times. There is an application restriction of twice per season for newly set plants.

\section{Sulfur}

Sulfur is used to manage anthracnose and powdery mildew (23). The median price of sulfur is $\$ 1$ per pound of active ingredient and the approximate cost per application is $\$ 22$ per acre $(8,23)$. The PHI and REI for sulfur are both 24 hours (21). Seventeen percent of surveyed papaya growers in Florida applied sulfur twice to the crop.

\section{Nematode Management}

\section{Nematode Pests}

Plant-parasitic nematodes are microscopic roundworms, found in soils, which primarily attack plant roots. General signs of nematode damage include stunting, premature wilting, leaf yellowing, root malformation, and related signs characteristic of nutrient deficiencies. Stunting and poor stand development tend to occur in patches throughout the field as a result of the irregular distribution of nematodes within the soil. Species of nematodes reported to be associated with papaya plants include Rotylenchulus reniformis, Meloidogyne spp., Helicotylenchus dihysteria, Quinisulcius acutus, and Criconemella spp. (22). The first two genera are by far the most damaging to papaya (19).

$R$. rotylenchulus (reniform nematode) is small in size and does not traverse distances of more than a few inches during its life. The nematodes are primarily spread through cultivation and surface runoff or through irrigation water. After molting several times, mature females penetrate the root cortex and become sedentary. Phloem feeding by the nematode creates giant cells, which are centers of high metabolic activity that compete with other parts of the plant for nutrients. The portion of the body that remains outside the root enlarges and becomes kidney-shaped. After mating, the female secretes a gelatinous substance around her body into which approximately 100 eggs are laid. When roots are washed clean, these egg masses appear like grains of sand. A complete life cycle is possible in about 25 days (4).

Papaya is susceptible to galling by the four common species of root-knot nematode. Many of the aspects of root-knot attack are similar to the reniform nematode. However, unlike reniform nematodes, the female root-knot nematode and associated egg-mass are embedded in the root tissue. Each egg mass may contain 350 eggs and 14-17 generations are possible in a year under subtropical conditions. In addition to the metabolic drain from feeding as described above, root systems may be reduced by terminal root infections, which cause a slight swelling and cessation of further elongation. Nutrient and water uptake are also impaired (4).

\section{Chemical Control}

The only products registered for use on papaya in Florida that claim nematode suppression are harpin protein (a mixture of plant extracts marketed as $\operatorname{Sincocin}^{\mathrm{Tw}}$ ) and fermentation products of Myrothecium verrucaria strain AARC-0255. Harpin protein activates the systemic acquired resistance of a plant, using the endogenous immune system of the plant to ward off nematode attack. Myrothecium verrucaria is a soil fungus that affects juvenile and adult nematodes as well as egg development. The mixture of plant extracts stimulates predatory nematode feeding and inhibits parasitic nematodes.

\section{Key Contacts}

Jonathan Crane is a professor of horticultural science located at the Tropical Research and Education Center in South Florida. He is responsible for research and extension duties associated with tropical fruit. Dr. Crane can be reached at: TREC, 18905 SW 280th St., PO Box 111569, Homestead, FL 33031-3314, (305) 246-7001, jhcr@ufl.edu.

Mark Mossler is a Doctor of Plant Medicine in the Agronomy Department's Pesticide Information Office at University of Florida, Institute of Food and Agricultural Sciences. He is responsible for providing pest management and pesticide information to the public and governmental agencies. Dr. Mossler can be reached at UF/IFAS PIO, Box 110710, Gainesville, FL 32611, (352) 392 4721, plantdoc@ ufl.edu

\section{References}

1. Personal communication, Jonathan Crane, October 2008. 
2. Crane, J.H., Balerdi, C.F., and Orfanedes, M.S. 2007. Tropical and Subtropical Fruit Crops for the Home Landscape: Alternatives to Citrus. Horticultural Sciences document HS812. Florida Cooperative Extension Service, Institute of Food and Agricultural Sciences, University of Florida.

3. Crane, J.H. 2005. Papaya Growing in the Florida Home Landscape. Horticultural Sciences document HS11. Florida Cooperative Extension Service, Institute of Food and Agricultural Sciences, University of Florida.

4. Compendium of Tropical Fruit Diseases. Ed. R.C. Ploetz. 1998. The American Phytopathology Society Press, St. Paul, MN.

5. Pena, J.E., and Johnson, F.A. 2006. Insect Management in Papaya. Entomology and Nematology document ENY-414. Florida Cooperative Extension Service, Institute of Food and Agricultural Sciences, University of Florida.

6. Selman, H.L. 2007. Papaya Fruit Fly. Department of Entomology and Nematology, University of Florida, and Florida Department of Agriculture and Consumer Services, Division of Plant Industry Featured Creatures website.

7. Weems, H.V. 1969. Papaya Fruit Fly (Toxotrypana curvicauda Gerstaecker), 1860 (Diptera: Tephritidae). Florida Dept. Of Ag. Div. Of Plant Industry Entomology Circular No. 86.

8. Fasulo, T.R. and Denmark, H.A. 2007. Twospotted Spidermite. Department of Entomology and Nematology, University of Florida, and Florida Department of Agriculture and Consumer Services, Division of Plant Industry Featured Creatures website.

9. UF/IFAS Pesticide Information Office. 2001. Tropical Fruit Management Survey. Agronomy Department, Institute of Food and Agricultural Sciences, University of Florida.

10. Crane, J.H. and Mossler, M.A. 2006. Pesticides Registered for Tropical Fruit Crops in Florida. Horticultural Sciences document HS929. Florida Cooperative Extension Service, Institute of Food and Agricultural Sciences, University of Florida.

11. Anonymous pesticide pricing.
12. FMC labels, Philadephia, PA.

13. Arysta labels, Cary, NC.

14. Webb Wright labels, ft. Myers, FL.

15. Knapp, J.L. February 1999. Citrus Commodity: A Biologic and Economic Assessment of Pesticide Usage. USDA National Agricultural Pesticide Impact Assessment Program Report No. 1-CA-99.

16. Monsanto labels, St. Louis, MO.

17. Syngenta labels, Research Triangle Park, NC.

18. DuPont labels, Wilmington, DE.

19. Pernezny, K. and Litz, R.E. 2003. Some Common Diseases of Papaya in Florida. Plant Pathology Department Document PP35. Florida Cooperative Extension Service, Institute of Food and Agricultural Sciences, University of Florida.

20. Dow AgroSciences labels, Indianapolis, IN.

21. Drexel labels, Memphis, TN.

22. McSorley, R., Parrado, J.L., and Conover, R.A. 1983. Population Buildup and Effects of the Reniform Nematode on Papaya in Southern Florida. Proc. Fla. State Hort. Soc. 96:198-200. 